\title{
EFFECTS OF AIR POLLUTION ON MORPHOLOGICAL CHARACTERISTICS OF CONES AND POLLENS OF PINUSSYLVESTRISL
}

\author{
Jamiyansuren S, Tsengel B \\ Department of Forest Science, National University of Mongolia \\ tsengel@num.edu.mn
}

\begin{abstract}
The aim of this study is to determine the morphological characteristics of cones and pollens of Pinus sylvestris $L$ (Scots pine). The average length of the pollen was measured $9.3 \mu \mathrm{m}$, and the width was $11.4 \mu \mathrm{m}$. Comparing to results of previous studies conducted by Jamyansuren S. and Suntsov A. B during the period of 1983 to 1985, the current morphological measurements of cones have decreased by $5 \mathrm{~mm}$ and number of cone scales reduced by 12.6 .
\end{abstract}

KEY WORDS: embryo sac , anomalism, shard, color

\section{INTRODUCTION}

The study of the morphological characteristics of the Scots spine is only at the beginning stage in Mongolia. Yet, we have demand to study changes in these characteristics in a relation with climate change and environmental conditions because they are highly influenced by the seed quality and their morphological characteristics of Scots pine. Our

\section{METHODS}

Cone and pollen samples were taken from Scots pine forest in Jargalant pass of Bogd Khan Mountain which elevated $1740 \mathrm{~m}$ above sea level (N47 $48^{\prime} 56.8^{\prime \prime}$ E106 $\left.51^{\prime} 48.1 "\right)$. For determining of morphological characteristics of pollen and cone of Scots pine, we have used XSP-8CA microscope, WVCP240EX camera, CGOne Card Performance computer program, digital camera and callipers. The measurements of morphological characteristics are averaged by 100 cones and pollens (Vidyakin A.I). investigation focused to obtain effects of climatic factors on seed quality and their morphological characteristics. Since we have data from previous study by Jamyansuren S. and Suntsov A.B on Scots pine forests in Bogd Khaan mountain from 19831985, we were able to compare our results with results of this study.

The coefficient of variation of morphological characteristics, and maximum, minimum means of pollen and cone of Scots pine by using Microsoft EXCEL 2010 (Mamaev1972) were calculated. All cones were categorized into five colors such as darkbrown, brown, brown-green, yellow-green and whitegreen (Jamyansuren S 1985).

Measurements of pollen characteristics were done by its length and width, length and width of pollen body, and length and width of air sacks. 


\section{RESULTS}

The current and averaged morphological characteristics of 100 samples were measured by length and width of cones, and number of cone scales. Average length of cones ranges $36.3 \pm 1.1 \mathrm{~mm}$ (max was 47 and min was 22.7) with $\mathrm{Cv} \%$ of 14.3 , while width measured $18.7 \pm 0.5 \mathrm{~mm}$ ( $\max$ was 26 and min was 14.4) with $\mathrm{C}_{\mathrm{v}} \%$ of 13.3. The number of cone scales counted $63.5 \pm 1.7$ ( $\max$ was 80 and min was 41) with $\mathrm{C}_{\mathrm{v}} \%$ of 12.7. According to the color categories of cones, about $7 \%$ of cones were black brown, $14 \%$ were brown, $14 \%$ were dark green, $55 \%$ were light green and $10 \%$ were yellow green.

The average length of pollen were $65.2 \pm 1.1 \mu \mathrm{m}$ (max was 80.8 and min was 50.34 ) with $\mathrm{Cv} \%$ of 9.5 , while width measured $40.2 \pm 0.7 \mu \mathrm{m}$ (max was 54.8 and $\min$ was 28.02) with $\mathrm{C}_{\mathrm{v}} \%$ of 10.6. The average length of pollen body was measured $44.7 \pm 0.9 \mu \mathrm{m}$ (max was 59.74 and min was 35.54 ) with $\mathrm{Cv} \%$ of 10.9 , while its width measured $34.2 \pm 0.8 \mu \mathrm{m}$ ( $\max$ was 48.33 and min was 21.64) with $\mathrm{C}_{\mathrm{v}} \%$ of 12.9 . The air sack length measured $26.0 \pm 0.5 \mu \mathrm{m}$ (max was 37.24 and min was 13.28) with $\mathrm{C}_{\mathrm{v}} \%$ of 16.6. Its width was $20.6 \pm 0.4 \mu \mathrm{m}$ (max was 30.42 and min was 11.3 ) with $\mathrm{C}_{\mathrm{v}} \%$ of 18.4.
During these morphological measurements, we also found that there were some abnormal developments of pollen under high-resolution microscope (Figures $1-4)$. Among the all samples, $11.7 \%$ of total pollens were observed with abnormal development.

Moreover, we compared these results with previously studied morphological characteristics of cones and pollens from Scots pines that collected also from BogdKhaan Mountain by Jamiyansuren $\mathrm{S}$ and Suntsov A.B from 1983-1985. Their measurements were: Average length of cones ranges $41.3 .3 \pm 0.5 \mathrm{~mm}$ (max 49.8 and $\min 34.4$ were respectively) with $\mathrm{Cv} \%$ of 8.9 , and the numbers of cone scales noted $76.1 \pm 1.3$ (max 94 and min 49 were.) with $\mathrm{C}_{\mathrm{v}} \%$ of 12.1 . The length of pollen means by $74.5 \pm 0.5 \mu \mathrm{m}(\max 77.5$ and $\min 68.2$ ) with $\mathrm{Cv} \%$ of 3.5 and $51.6 \pm 0.5 \mu \mathrm{m}$ (max 55.2 and $\min 46.1)$ with $\mathrm{Cv} \%$ of 4.9 in width. The pollen body length $54.2 \pm 0.4 \mu \mathrm{m}$ ( $\max 58.4$ and $\min$ 48.8) with $\mathrm{Cv} \%$ of 4.3 and the width $43.5 \pm 0.5 \mu \mathrm{m}$ ( $\max 49.3$ and $\min 37.8$ ) with $\mathrm{Cv} \%$ of 6.2 were measured respectively.

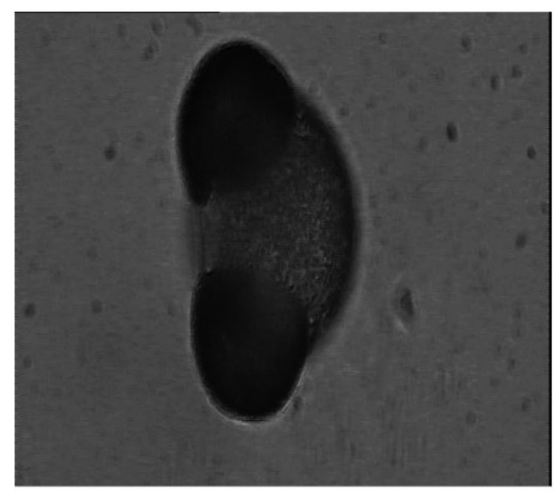

Figure 1. Morphology of normal pollen
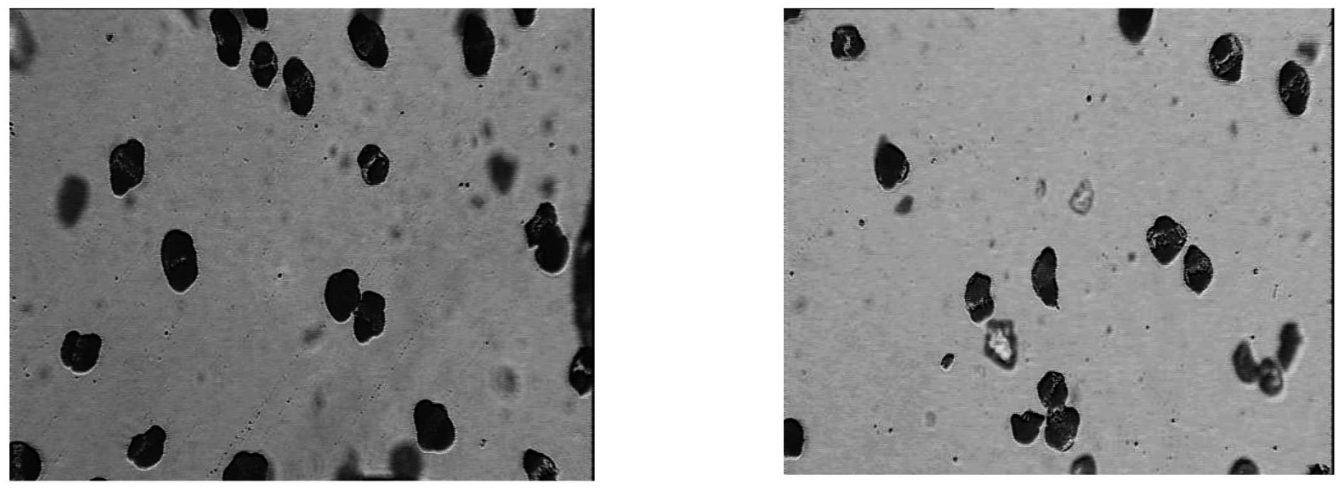

Figure 2. General view of pollens under 10X resolution microscope 


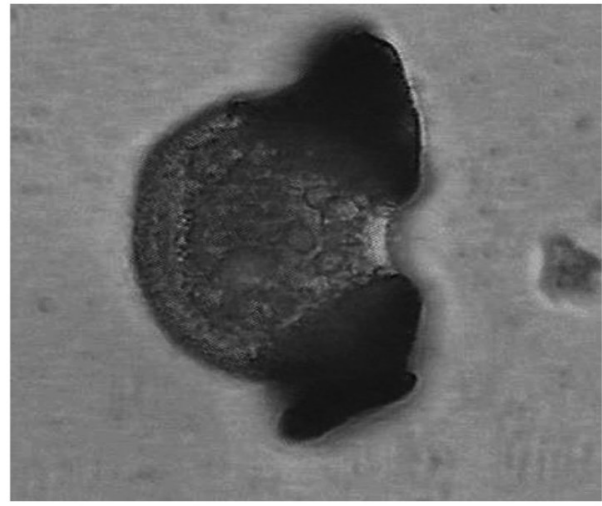

Pollen with underdeveloped air sacks

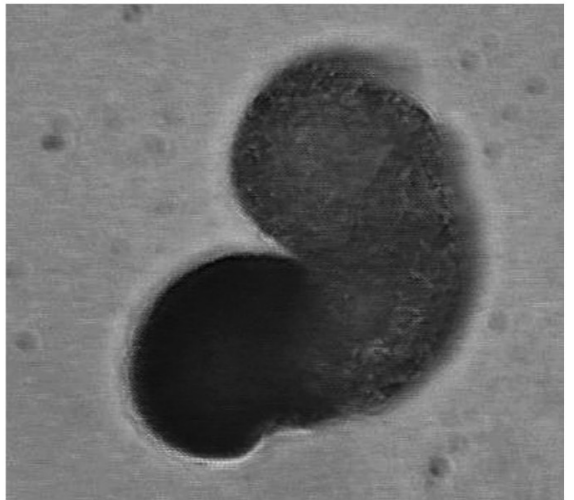

Pollen without one air sack

Figure 3. Abnormal morphologies of pollens
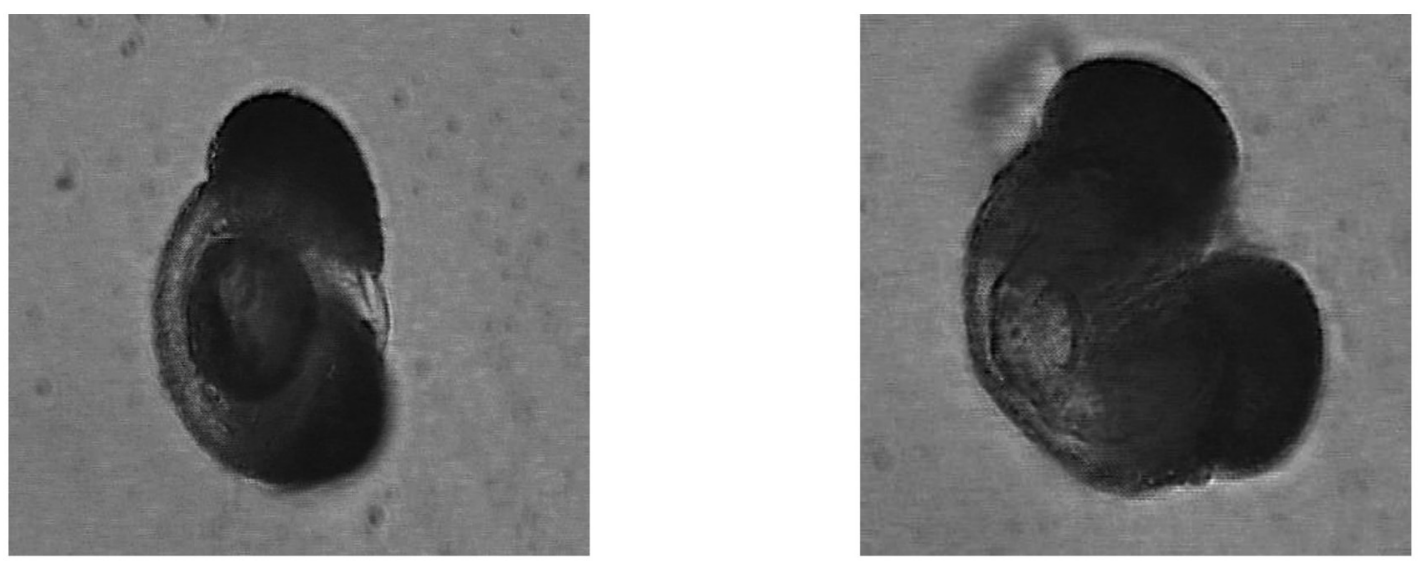

Figure 4. pollens with 3 air sacks (abnormal morphology)

Compared results of morphological characteristics of cones for these two studies were showed in table 1 and pollens in table 2.

Table 1

Morphological changes in cones

\begin{tabular}{ccc}
\hline year of study & Length of cones,mm /averaged/ & Number of cone scales /averaged/ \\
\hline 1983 & 41.3 & 76.1 \\
2012 & 36.3 & 63.5 \\
$1983-2012$ & 5 & 12.6 \\
\hline
\end{tabular}

Table 2

Morphological changes of pollens.

\begin{tabular}{ccccc}
\hline $\begin{array}{c}\text { Year of } \\
\text { study }\end{array}$ & Pollen length, $\mu \mathrm{m}$ & Pollen width, $\mu \mathrm{m}$ & $\begin{array}{c}\text { Length of pollen } \\
\text { body, } \mu \mathrm{m}\end{array}$ & $\begin{array}{c}\text { Width of pollen body, } \\
\mu \mathrm{m}\end{array}$ \\
\hline 1983 & 74.5 & 51.6 & 54.2 & 43.5 \\
2012 & 65.2 & 40.2 & 44,7 & 34.2 \\
$1983-$ & 9.3 & 11.4 & 9.5 & 9.3 \\
2012 & & & & \\
\hline
\end{tabular}


According to the meteorological data from 1983 to 2012 at BogdKhaan Mountain, the average temperature has increased by $+0.4^{\circ} \mathrm{C}-+0.8^{\circ} \mathrm{C}$ and temperature during the coldest period got warmer by $3^{\circ} \mathrm{C}-6^{\circ} \mathrm{C}$. Decreased morphological changes of pollens and cones for Scots pine are highly dependent on air pollution and not on climate change.

Also by observation of small sized and abnormality of pollens in BogdKhaan Mountain, our results were

\section{REFERENCE}

1. Базарсад Ч.Ойжуулалт, 2011 он, $24 \mathrm{x}$

2. Базарсад.Ч, Бат-эрдэнэ.Ж, Цэнгэл.Б, Ойн аж ахуйн үндсэн ажлууд, 2011он , 16x

3. Видякин А.И. Методические основы выделения фенов лесных древесных растений, 2010

4. Гомбосүрэн.Н, Цэнгэл.Б. Модлог ургамал судлал, $20120 н .87 \mathrm{x}$ confirmed. Consequently, these growing-up some of pollen abnormality shows that natural regeneration process of Scots pine will be limited in the future.

Accordingly, these abnormality and decreasing numbers of cones and pollens will shrink stand adaptation of Scots pine forests and their immunity in a facing climate change on natural regeneration of these forests in BogdKhaan Mountain.

5. Леса Монгольской Народной Республики. 1988.92-110x

6. Некрасова Т.П. Пылца и пылцевой режим хвойных Сибири, 1983г

7. УдвалБ. Эрдэм шинжилгээний бичиг Биологи №15(346) 2011 он 179x 